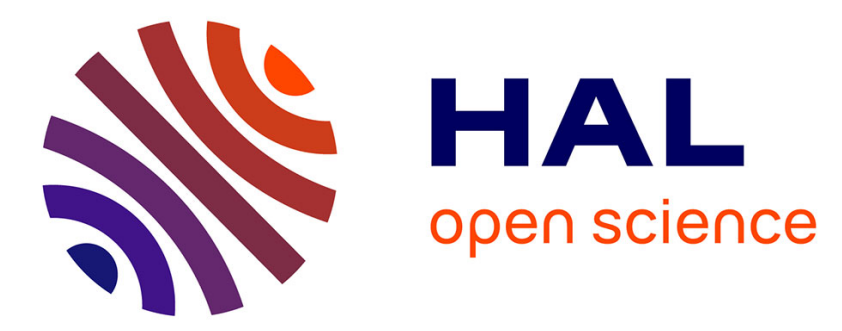

\title{
Influence assessment of inlet parameters on thermal risk and productivity: Application to the epoxidation of vegetable oils
}

Nelcis Zora, Thomas Rigaux, Jean-Christophe Buvat, Dimitri Lefebvre, Sébastien Leveneur

\section{To cite this version:}

Nelcis Zora, Thomas Rigaux, Jean-Christophe Buvat, Dimitri Lefebvre, Sébastien Leveneur. Influence assessment of inlet parameters on thermal risk and productivity: Application to the epoxidation of vegetable oils. Journal of Loss Prevention in the Process Industries, 2021, 72, pp.104551. 10.1016/j.jlp.2021.104551 . hal-03498083

\section{HAL Id: hal-03498083 https://hal.science/hal-03498083}

Submitted on 6 Jan 2022

HAL is a multi-disciplinary open access archive for the deposit and dissemination of scientific research documents, whether they are published or not. The documents may come from teaching and research institutions in France or abroad, or from public or private research centers.
L'archive ouverte pluridisciplinaire HAL, est destinée au dépôt et à la diffusion de documents scientifiques de niveau recherche, publiés ou non, émanant des établissements d'enseignement et de recherche français ou étrangers, des laboratoires publics ou privés. 
Influence assessment of inlet parameters on thermal risk and productivity: application to the epoxidation of vegetable oils

Nelcis Zora ${ }^{1}$, Thomas Rigaux ${ }^{1}$, Jean-Christophe Buvat ${ }^{1}$, Dimitri Lefebvre ${ }^{2}$ and Sébastien Leveneur ${ }^{1, *}$

1 Normandie Univ, INSA Rouen, UNIROUEN, LSPC, EA4704, 76000 Rouen, France; sebastien.leveneur@insa-rouen.fr

2 Université Le Havre - GREAH, 25 rue P. Lebon, 76063 Le Havre, France

* Correspondence: sebastien.leveneur@insa-rouen.fr; Tel.: +33-2329-566-54 (Fr)

Abstract: The influence of inlet parameters on the production and thermal risk of complex chemical systems can be cumbersome to evaluate. To determine the optimum safe operating conditions, one needs to solve complex differential equations derived from energy and material balances. This robust approach cannot be made on-site, and it is essential to propose simplest tools to evaluate rapidly the performance and safety of some operating conditions. This is the aim of this paper that establishes explicit relationships between the production and thermal risk parameters, and the inlet parameters. In addition, it also proposes a Pareto chart that can be used to make the tradeoff between safety and performance. Such relationships and chart were developed for the production of epoxidized cottonseed oil under isoperibolic and semi-batch mode. The kinetic model developed by Zheng et. (Zheng et al., 2016) was used. First, a numerical approach, i.e., least square method, was used to find explicit relationships between thermal risk parameters, production parameters and six inlet parameters. The use of such an approach allows a better understanding of this process. Second, safety and performance indicators are proposed and discussed to evaluate the operating conditions thanks to a simple and intuitive schema. Besides, this approach can be used to find the optimum conditions more rapidly.

Keywords: complex kinetics; thermal risk; optimization, linear regression, Pareto chart. 


\section{Introduction}

The determination of the optimum safe operating conditions of multiple exothermic reactions is challenging. For instance, the increase of reaction temperature favors a fast production but could also trigger side or secondary reactions and increase the risk of thermal runaway. The kinetic models for such a system can be quite complicated (several reactions, ordinary differential equations...), making tricky a simple analysis. A slight change in the operating conditions could have severe unwanted consequences on the maximum reaction temperature or the final yield. Kinetic models are constituted by several differential equations derived from energy and material balances. It can be complicated to handle such equations during the production processes to know the influence of inlet parameters on the reaction temperature, conversion or yield. In particular, the methodology proposed to find the best operating conditions is implementable without having to solve ODEs and to use any mathematical software or other advanced numerical tool. This could make sense in an industrial environment where such tools are not immediately available and where the operators have not necessarily the technical skills to parametrize and use ODE solvers. To help the operators, we proposed an approach to find explicit relationships between the reactor outputs (e.g., reaction temperature, concentration, yield...) and the inlet parameters. As mentioned by Dakkoune et al. (Dakkoune et al., 2019, 2018), the risk of thermal runaway is important in French and also in other European chemical industries, and the operator error is an important cause. Thus, the use of such an approach could improve the understanding of the processes and avoid risky situations.

One significant example of a complex chemical system is the epoxidation of vegetable oils by Pirleschajew oxidation under non-isothermal conditions (Casson Moreno et al., 2017; Leveneur et al., 2014b; Santacesaria et al., 2011; Zheng et al., 2016). Epoxidized vegetable oils can be considered as a platform molecule (Yan et al., 2018), and can be a promising substituent to petroleum-derived products. Indeed, different reactions can be done on the functional group, i.e., epoxide (Desroches et al., 2012). Epoxidized vegetable oils could also be a key intermediate for the production of nonisocyanate polyurethanes (Nohra et al., 2013; Pérez-Sena et al., 2018). Epoxidized vegetable oils can also be used as plasticizers (Hosney et al., 2018) or lubricants (Adhvaryu and Erhan, 2002; Cecilia et al., 2020; Lathi and Mattiasson, 2007). 
There are several routes for the production of epoxidized vegetable oils: the use of molecular oxygen (Danov et al., 2017; Köckritz and Martin, 2008; Scotti et al., 2015; Vanoye et al., 2016; Wentzel et al., 2004), the direct epoxidation by hydrogen peroxide (Parada Hernandez et al., 2017; Pérez-Sena et al., 2020; Sepulveda et al., 2007; Suarez et al., 2009; Turco et al., 2016) and the Prileschajew method through an in-situ produced percarboxylic acid. The use of molecular oxygen is appealing, but there is a risk of over combustion (Köckritz and Martin, 2008). Due to the low solubility of hydrogen peroxide in the organic phase, i.e., vegetable oils, more investigation is needed for the direct epoxidation by hydrogen peroxide.

The Prileschajew method is the most studied and most used in the academy and industry. It is a liquid-liquid reaction system where the percarboxylic acid is produced in the aqueous phase by the perhydrolysis of carboxylic acid. Then, the percarboxylic acid diffuses in the organic phase to epoxide the unsaturated group of the vegetable oils. There are several exothermic consecutive and parallel reactions for this system. The investigation regarding this system is on the development of robust kinetic models (Campanella and Baltanás, 2007, 2006; de Haro et al., 2016; Goud et al., 2007a; Jankovic and Sinadinovic-Fiser, 2004; Leveneur et al., 2014b; Osuna and Mendivelso, 2010; Rakotondramaro et al., 2016; Rangarajan et al., 1995; Santacesaria et al., 2011; Sinadinović-Fišer et al., 2012, 2001; Wu et al., 2016; Zheng et al., 2016), the use of heterogeneous catalyst (Goud et al., 2007b, 2007a; Gurbanov et al., 2005; Meshram et al., 2011; Mungroo et al., 2008; Sinadinović-Fišer et al., 2012, 2001), the use of enzymatic catalyst (Hagström et al., 2011; Hilker et al., 2001; Lu et al., 2010; Orellana-Coca et al., 2007, 2005; Rusch Gen Klaas and Warwel, 1999; Törnvall et al., 2007), the use of microwave irradiation (Aguilera et al., 2019a, 2019b, 2016; Leveneur et al., 2014a; Piccolo et al., 2019) and process safety (Casson Moreno et al., 2017; Leveneur, 2017; Leveneur et al., 2018, 2015; Rakotondramaro et al., 2016).

On the one hand, determining the optimal operating conditions to get the highest yield of epoxidized vegetable oils has been studied by different research groups (Arumugam et al., 2014; Milchert et al., 2010; Xu et al., 2017) with the design of experiments. On the other hand, finding safe operating conditions can be obtained with similar methods. Combining these two objectives to find safe operating conditions that get the highest yield can be difficult for this system and is a challenging task. This is the main objective of this work. Indeed, the advanced kinetic model for this system includes all possible reactions, thermal parameters and reaction enthalpies. Thus, one needs to 
develop explicit models for the thermal risk and production parameters. First, a complex numerical simulator has been developed from the study of Zheng et al.(Zheng et al., 2016) to describe the kinetics of the epoxidation of cottonseed oil in a semi-batch reactor under isoperibolic conditions. Then, an approach, based on least square method, was developed to find explicit relationships of second order from the inlet parameters to the parameters that characterize the thermal risk and the production. Such relationships make it possible to express the effects of inlet parameters (e.g., initial reaction temperature, volumetric flow-rate of the feed...) on the maximum reaction temperature $\left(T_{R, \max }\right)$, the time to reach this maximum reaction temperature $\left(t_{T R, \max }\right)$, the maximum epoxide concentration $\left(C_{E p, \max }\right)$ and the time to reach this maximum concentration $\left(t_{C E p, \max }\right)$. To verify the robustness of this approach, four explicit relationships for $T_{R, \max }, t_{T R, \max }, C_{E p, \max }$ and $t_{C E p, \max }$ were evaluated and compared with the numerical experiments. In addition, the numerical simulations have been proved to be also useful to find safe and efficient operating conditions through a Pareto chart approach. Finally, the validity of the explicit thermal risk relationships and Pareto chart were tested with some laboratory experiments. 


\section{Materials and Methods}

The proposed method is based on a four step methodology.

1. The first step is to develop a numerical simulator based on the kinetic model of the reaction system of interest. The design of such a simulator requires some expert knowledge both in chemical processes and in computer science. The numerical approach used to solve the ODEs is described in 4.1. In particular this simulator aims to compute, in an accurate way, output parameters i.e., the maximum reaction temperature $\left(T_{R, \max }\right)$, the time to reach this maximum reaction temperature $\left(t_{T R, \max }\right)$, the maximum epoxide concentration $\left(C_{E p, \max }\right)$ and the time to reach this maximum concentration $\left(t_{C E p, \max }\right)$ from the inlets parameter. The previous 4 outputs have been selected because they characterize the performance and also the safety of the process. Concerning the inputs, we have restricted our study to inlet parameters whose value may be directly or indirectly be tuned by the operators (Figure 1).

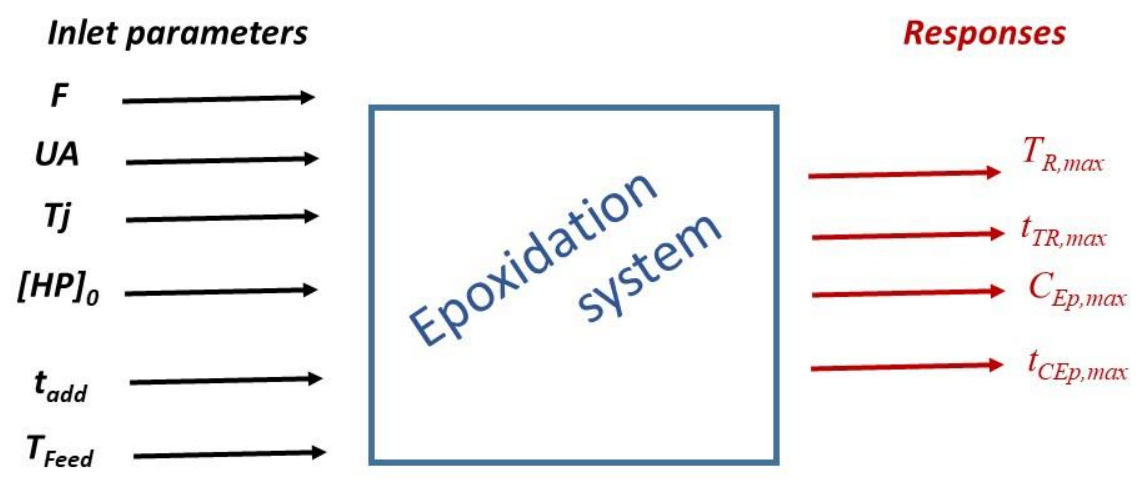

Figure 1. Inlet parameters and responses for the epoxidation system.

2. The second step is to validate the proposed simulator by a set of practical experimentations. Again, expert knowledge in chemical processes is required for this validation. Laboratory experiments, following Zheng et al.(Zheng et al., 2016) protocol was used. Briefly, epoxidation of cottonseed oil was carried out in a semi-batch reactor under isoperibolic mode. Formic acid was added in the reactor. The equipment to carry out these experiments was the same than for Zheng et al.(Zheng et al., 2016). 
In the perspective of the authors it is clear that steps 1 and 2 impose some limitations in their use due to the high level of qualification required. Observe, however, that an easy and rapid evaluation of the thermal risk and production performance will be helpful in many situations. This motivates steps 3 and 4 of the proposed methodology.

3. Step 3 aims to propose an input / output mapping of the parameters of interests based on linear regression. Let us consider $I n=\left\{p_{1}, \ldots, p_{n+1}\right\}$ as the set of the $n$ inlet parameters $p_{i}, i=1, \ldots, n$ and $p_{n+1}$ $=1$, and Out $=\left\{q_{1}, \ldots, q_{p}\right\}$ as the set of $p$ output parameters that are of interest for the considered study. What is proposed in this paper is to generate a second order mapping resulting from series of $N$ simulations obtained thanks to the numerical simulator developed in step 1 . The appropriate regression has been selected according to a trade-off between the regression error (precision) and the number of parameters of the regressive model (complexity). A first order regression was not enough to represent the considered outputs and a third order regression was poorly tractable. Finally, once the set of inlet parameters as their range and the order of the regression have been fixed, the computation of the regression results from the mean square method and the system simulator. For regression purpose, one computes the matrix $M$ of dimension $N \times(n+2) \cdot(n+1) / 2$ of the form:

$M=\left(p^{2}{ }_{k, 1} p_{k, 1} \cdot p_{k, 2} p_{k, 1} \cdot p_{k, 3} \ldots p_{k, 1} \cdot p_{k, n+1} p_{k, 2}^{2} p_{k, 2} \cdot p_{k, 3} \ldots p_{k, i} \cdot p_{k, j} \ldots p_{k, n}^{2} p_{k, n} \cdot p_{k, n+1} p^{2}{ }_{k, n+1}\right), k=1, \ldots, N$

where each entry $p_{k, i} \cdot p_{k, j}$ of $M$ results from the product of the value of two inlet parameters $p_{k, i}$ and $p_{k, j}$ with $i=1, \ldots, n, j=1, \ldots, n, j \geq i$. The indices $k=1, \ldots, N$ refer to the $k$ th simulation.

Similarly, we consider the $q$ output parameter vectors $Y_{j}=\left(q_{k, j}\right), k=1, \ldots, N$ for $j=1, \ldots, q$ where $q_{k, j}$ refers to the value of parameter $q_{j}$ returned by $k$ th simulation. From the matrix $M$ and the vector $Y_{j}$, one can compute the vector $X_{j}$ of the $(n+2) .(n+1) / 2$ coefficients that define the mapping from the $n$ inlet parameters $p_{i}, i=1, \ldots, n$ to $q_{j}$. In particular, as far as $M$ is of full column rank, we have:

$X_{j}=\left(M^{T} \times M\right)^{-1} \times M^{T} \times Y_{i}$ 
4. A Pareto chart is calculated from the obtained mappings (see section 4.5 for details). The basic idea to compute such a chart is to define two global indicators based on 4 output parameters that are of interest, i.e., the maximum reaction temperature $\left(T_{R, \max }\right)$, the time to reach this maximum reaction temperature $\left(t_{T R, \max }\right)$, the maximum epoxide concentration $\left(C_{E p, \max }\right)$ and the time to reach this maximum concentration $\left(t_{C E p, \max }\right)$. Such a chart is helpful to select the values of the inlet parameters that lead to the best tradeoff between the thermal safety and the performance in production.

\section{Kinetic model}

In this section, the kinetic model of the epoxidation of vegetable oils by Pirleschajew oxidation under non-isothermal conditions developed by Zheng et al.(Zheng et al., 2016) is detailed. The experiments were performed in a semi-batch reactor under isoperibolic conditions. A solution of formic acid was fed into the reactor, containing initially hydrogen peroxide, water and cottonseed oil solution.

The reaction steps are described in Figure 2. In the first step, hydrogen peroxide and formic acid react to produce performic acid. Due to its high reactivity, the performic acid can be decomposed by two different routes (Leveneur et al., 2012). The performic acid can also diffuse to the organic phase to epoxidize the unsaturated groups. The epoxide group can be attacked by different nucleophiles, which is the ring-opening reaction (Cai et al., 2018).

\section{AQUEOUS PHASE}

$$
\begin{gathered}
\mathrm{HCOOH}+\mathrm{H}_{2} \mathrm{O}_{2} \stackrel{\text { Perhydrolysis }}{\rightleftarrows} \mathrm{H}_{2} \mathrm{O}+\mathrm{HCO}_{3} \mathrm{H} \\
\mathrm{HCO}_{3} \mathrm{H} \stackrel{\text { Decomposition } 1}{\longrightarrow} \mathrm{CO}_{2}+\mathrm{H}_{2} \mathrm{O} \\
\mathrm{HCO}_{3} \stackrel{\text { Decomposition } 2}{\longrightarrow} \mathrm{HCOOH}+1 / 2 \mathrm{O}_{2}
\end{gathered}
$$

\section{ORGANIC PHASE}
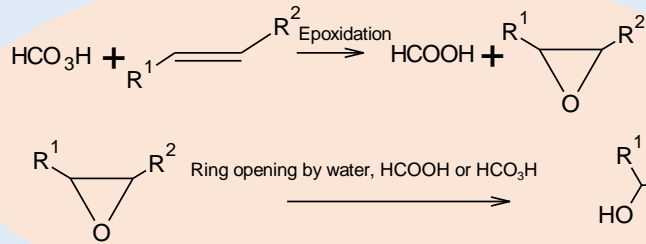

Figure 2. Reaction steps for the epoxidation system.

The underlying assumption made by Zheng et al. (Zheng et al., 2016) was that mass transfer is rapid compared to reaction kinetics. Thus, the equilibrium molar ratio of a compound $i$ can be expressed as 


$$
\mathrm{K}_{\mathrm{i}}=\frac{[\mathrm{i}]_{\mathrm{aq}}^{*}}{[\mathrm{i}]_{\mathrm{org}}^{*}} \approx \frac{[\mathrm{i}]_{\mathrm{aq}}}{[\mathrm{i}]_{\mathrm{org}}}
$$

where, $[i]_{a q}^{*}$ and $[i]_{\text {org }}^{*}$ are the concentrations of compound $i$ at the aqueous and organic side of the interface.

-The perhydrolysis of carboxylic acid is a reverisble reaction which can be self-catalyzed due to the dissociation of carboxylic acid (Leveneur et al., 2012, 2009, 2008). This reaction occurs in the aqueous phase (Santacesaria et al., 2011; Zheng et al., 2016). The application of electroneutrality leads to express the hydroxonium concentration as $\left[H_{3} O^{+}\right]_{a q}=\sqrt{K_{F A D}^{C} \cdot[W]_{a q} \cdot[F A]_{a q}}$. By applying quasi-equilibrium hypothesis, one can derive the rate of formic acid prhydrolysis as

$R_{\text {Perh }}=k_{\text {Perh }} \cdot \sqrt{K_{F A D}^{C} \cdot \frac{[F A]_{a q}}{[W]_{a q}}} \cdot\left([F A]_{a q} \cdot[H P]_{a q}-\frac{1}{K^{C}} \cdot[P F A]_{a q} \cdot[W]_{a q}\right)$

where, the term $\mathrm{K}_{\mathrm{FAD}}^{\mathrm{C}}$ states for the dissociation of formic acid (Harned and Embree, 1934), and $K^{C}$ is the equilibrium constant expressed by a van't Hoff law with $K^{C}=0.96$ at $30^{\circ} \mathrm{C}$ and $\Delta H_{P e r h}=$ $-5580 \mathrm{~J} / \mathrm{mol}$ (Zheng et al., 2016).

-The epoxidation reactions were supposed to be elementary steps occuring in the organic phase between performic acid and unsaturated groups. As mentionned earlier, the mass tranfer is supposed to be faster than chemical reactions, then $[P F A]_{\text {org }}=\frac{[P F A]_{a q}}{K_{P F A}}$, and the rates are:

$R_{E p, 1}=k_{E p, 1} \cdot \frac{[P F A]_{a q}}{K_{P F A}} \cdot[C 18: 1]_{\text {org }}=k_{E p, 1}^{\prime} \cdot[P F A]_{a q} \cdot[C 18: 1]_{o r g}$

$R_{E p, 2}=k_{E p, 2} \cdot \frac{[P F A]_{a q}}{K_{P F A}} \cdot[C 18: 2]_{o r g}=k_{E p, 2}^{\prime} \cdot[P F A]_{a q} \cdot[C 18: 2]_{o r g}$

$R_{E p, 3}=k_{E p, 3} \cdot \frac{[P F A]_{a q}}{K_{P F A}} \cdot[\text { Int }]_{\text {org }}=k_{E p, 3}^{\prime} \cdot[P F A]_{a q} \cdot[\text { Int }]_{\text {org }}$

where, the terms $[C 18: 1]_{\text {org }},[C 18: 2]_{\text {org }}$ and $[\operatorname{Int}]_{\text {org }}$ are the concentrations of the fatty acid chains on the triglyceride.

-Decomposition of performic acid, ocurring in the aqueous phase, follows a first order and are expressed as 
$R_{\text {Decomp }, 1}=k_{\text {Decomp }, 1} \cdot[P F A]_{a q}$

$R_{\text {Decomp }, 2}=k_{\text {Decomp }, 2} \cdot[P F A]_{a q}$

-The ring-opening reaction, occuring in the organic phase, can be due to the nucleophilic attack of water, formic acid or performic acid (Zheng et al., 2016). The first step is the protonation of the oxirane group, then in the second step the nucleophilic agents react with the activated oxirane group. The quasi-equilibrium hypothesis is applied on the first step leading to express the concentration of the activated oxirane group as $[$ Activated oxirane $]=\frac{K_{\text {First step }[}[\mathrm{Ep}]_{\mathrm{org}} \cdot\left[\mathrm{H}_{3} \mathrm{O}^{+}\right]_{\text {org }}}{\left[\mathrm{H}_{2} \mathrm{O}\right]_{\mathrm{org}}}$. The concentration of hydroxonium ion in the organic phase is $\left[\mathrm{H}_{3} \mathrm{O}^{+}\right]_{\mathrm{org}}=\frac{\left[\mathrm{H}_{3} \mathrm{O}^{+}\right]_{a q}}{K_{\mathrm{H}_{3} \mathrm{O}^{+}}}=\frac{\sqrt{\mathrm{K}_{\mathrm{FAD}}^{\mathrm{C}} \cdot[\mathrm{W}]_{a q} \cdot[\mathrm{FA}]_{a q}}}{K_{\mathrm{H}_{3} \mathrm{O}^{+}}}$and water in the organic phase is $[W]_{\text {org }}=\frac{[W]_{a q}}{K_{W}}$. The second step is the rate determining step, and thus, the rate equations for the ring-opening by water, hydrogen peroxide, formic acid and performic acid were derived as

$$
\begin{gathered}
R_{R O W}=k_{R O W}^{\prime} \cdot[E p]_{o r g} \cdot \sqrt{K_{F A D}^{C} \cdot[\mathrm{W}]_{a q} \cdot[\mathrm{FA}]_{a q}} \\
R_{R O F A}=k_{R O F A}^{\prime} \cdot[E p]_{o r g} \cdot[F A]_{a q} \cdot \sqrt{\frac{K_{F A D}^{C} \cdot[F A]_{a q}}{[W]_{a q}}} \\
R_{R O P F A}=k_{R O P F A}^{\prime} \cdot[E p]_{o r g} \cdot[P F A]_{a q} \cdot \sqrt{\frac{K_{F A D}^{C} \cdot[F A]_{a q}}{[W]_{a q}}}
\end{gathered}
$$

where, $k_{R O W}^{\prime}, k_{R O F A}^{\prime}$ and $k_{R O P F A}^{\prime}$ are merged kinetic constants.

Note that all parameters used in the equations are explained in a nomenclature at the end of the paper. In addition, units and values of the parameters are detailed in Supplementary material. 
The material balance of a compound $i$ in the aqueous phase is written as

$\dot{n}_{i, a q, i n}+\sum v_{i j} \cdot V_{a q} \cdot r_{a q, j}=\frac{d n_{i, a q}}{d t}+N_{i} \cdot A^{\prime}$

where, $\dot{n}_{i, a q, i n}$ is the inlet molar flow of compound $i(\mathrm{~mol} / \mathrm{s}), v_{i j}$ is the coefficient stoichiometric of the compound $i$ is in reaction $j, r_{a q, j}$ is the reaction rate $j$ in the aqueous phase (mol/L/s), $V_{a q}$ is the volume of aqueous phase (L), $n_{i, a q}$ is the amount of $i$ in the reactor (mol) and $N_{i} \cdot A^{\prime}$ is the outler molar flow of coumpound $i$ from the aqueous to organic phase (mol/s). The term $N_{i}$ is the diffusion flux of the compound $i\left(\mathrm{~mol} / \mathrm{m}^{2} / \mathrm{s}\right)$ and $A^{\prime}$ is the interfacial area $\left(\mathrm{m}^{2}\right)$.

The following notations are introduced: $a=\frac{A^{\prime}}{V_{T}}\left(\mathrm{~m}^{2} / \mathrm{L}\right), \tau=\frac{V_{T}}{Q_{a q}}(\mathrm{~s}), \tau_{a q}=\frac{V_{a q}}{Q_{a q}}(\mathrm{~s})$ and $\alpha=\frac{\tau_{a q}}{\tau}=\frac{V_{a q}}{V_{T}}$. The terms $V_{T}$ is the total volume, and $Q_{a q}$ is the volumetric flow rate of aqueous solution (L/s), which is the solution of formic acid. Then, Equation 13 becomes

$\frac{d C_{i, a q}}{d t}=\sum v_{i j} \cdot r_{a q, j}-\frac{N_{i} \cdot a}{\alpha}+\frac{\left(C_{F e e d, i}-C_{i, a q}\right)}{\tau_{a q}}$

where, $C_{i, a q}$ is the concentration of $i$ in the aqueous phase and $C_{F e e d, i}$ is the concentration of $i$ in the feed.

The solubility of vegetable oil species in the aqueous phase is assumed to be negligible. Hence, the material balance of a compound $i$ in the organic phase is written as

$\sum v_{i j} \cdot V_{\text {org }} \cdot r_{\text {org }, j}+N_{i} \cdot A^{\prime}=\frac{d n_{i, o r g}}{d t}$

where, $V_{\text {org }}$ is the volume of the organic phase $(\mathrm{L}), r_{\text {org }, j}$ is the rate of reaction $\mathrm{j}$ in the organic phase (mol/L/s) and $n_{i, o r g}$ is the amount of compound $i$ in the organic phase.

The notation $\beta=\frac{V_{\text {org }}}{V_{T}}$ is introduced, and $\alpha+\beta=1$. Then, Equation 15 becomes

$\frac{d c_{i, o r g}}{d t}=\frac{N_{i} \cdot a}{\beta}+\sum v_{i j} \cdot r_{\text {org }, j}=\frac{N_{i} \cdot a}{1-\alpha}+\sum v_{i j} \cdot r_{\text {org }, j}$

By adding Equations 14 and 16, one gets

$\alpha \cdot \frac{d c_{i, a q}}{d t}+(1-\alpha) \cdot \frac{d c_{i, o r g}}{d t}=\alpha \cdot \sum v_{i j} \cdot r_{a q, j}+(1-\alpha) \cdot \sum v_{i j} \cdot r_{o r g, j}+\alpha \cdot \frac{\left(C_{F e e d, i}-C_{i, a q}\right)}{\tau_{a q}}$ 
From Equation 3, one gets $\frac{d c_{i, a q}}{d c_{i, o r g}}=K_{i}$. Hence, the material balances in a semi-batch reactor for a compound $i$ are expressed as

$\frac{d c_{i, o r g}}{d t}=\left(\alpha \cdot K_{i}+1-\alpha\right)^{-1} \cdot\left(\left(\alpha \cdot \sum v_{i j} \cdot r_{a q, j}+(1-\alpha) \cdot \sum v_{i j} \cdot r_{\text {org }, j}\right)+\alpha \cdot \frac{\left(c_{\text {feed }, i}-K_{i} \cdot c_{i, o r g}\right)}{\tau_{a q}}\right)$

$$
\frac{d C_{i, a q}}{d t}=\left(\alpha+\frac{1-\alpha}{K_{i}}\right)^{-1} \cdot\left(\left(\alpha \cdot \sum v_{i j} \cdot r_{a q, j}+(1-\alpha) \cdot \sum v_{i j} \cdot r_{o r g, j}\right)+\alpha \cdot \frac{\left(C_{f e e d, i}-C_{i, a q}\right)}{\tau_{a q}}\right)
$$

This approach allows avoiding to estimation the mass transfer coefficients. The equilibrium molar ratio of the different compounds have the following values:

$K_{P F A} \approx K_{F A} \rightarrow 9$

$K_{H P}$ and $K_{W} \rightarrow \infty$,

$K_{C 18: 1}, K_{C 18: 2}, K_{I n t}, K_{E p}$ and $K_{\text {Degradation by } R O} \rightarrow 0$.

The energy balance on the reaction mixture under isoperibolic conditions was derived as

$\frac{d T_{R}}{d t}=\left(\frac{1}{m_{R} \cdot C_{P R}}\right)$

$$
\begin{aligned}
& \cdot\left[\left(-V_{a q}\right.\right. \\
& \cdot\left(R_{\text {Perh }} \cdot \Delta H_{R, \text { Perh }}+R_{\text {Decomp }, 1} \cdot \Delta H_{R, \text { Decomp }, 1}+R_{\text {Decomp }, 2} \cdot \Delta H_{R, \text { Decomp }, 2}\right)-V_{\text {org }} \\
& \left.\cdot\left(\left(R_{E p, 1}+R_{E p, 2}+R_{E p, 3}\right) \cdot \Delta H_{R, E p}+\left(R_{R O W}+R_{R O F A}+R_{R O P F A}\right) \cdot \Delta H_{R, R O}\right)\right)+\mathrm{UA} \\
& \left.\cdot\left(T_{j}-T_{R}\right)+\mathrm{F} \cdot C_{F A, F e e d} \cdot \overline{C_{p, F A}} \cdot\left(T_{F e e d}-T_{R}\right)\right]
\end{aligned}
$$

The term $U A$ is the global heat transfer coefficient between the heat carrier and the reaction mixture.

The term $\overline{C_{p, F A}}$ stands for the molar heat capacity of formic acid. The value of $C_{P R}$ was calculated by using the data from Zheng et al. (Zheng et al., 2016). The kinetic and thermodynamic constants regarding with reaction system can be found in Supplementary material. 
From the material and energy balances usebd by Zheng et al. (Zheng et al., 2016), one can notice that the following inlet parameters: $F, U A, T j,[H P]_{0}, t_{a d d}$ and $T_{\text {Feed }}$ have an influence on the four responses as illustrated by Scheme 1. During their kinetic experiments, Zheng et al. (Zheng et al., 2016) varied these inlet parameters to develop their kinetic model. For these reasons, these inlet parameters were chosen to make the design of experiments.

\section{Results and discussion}

In this section, the results of the numerical experiments are presented and discussed.

\subsection{Numerical experiments}

The ordinary differential Equations 18-20 were solved out by a modified Rosenbrock formula of order 2 , allowing to solve stiff equations. The influence of six inlet parameters on the four responses $\left(T_{R, \max }\right.$, $t_{T R, \max }, C_{E p, \max }$ and $\left.t_{C E p, \max }\right)$ was studied.

Table 1 presents the variation of the six parameters. It is important to stress that the ranges of variation of the inlet parameters used in this study are the same as the ones of Zheng et al. (Zheng et al., 2016). Thus, these ranges were used where the reliability of the Zheng's model was experimentally verified.

Table 1. Variation of the inlet parameters.

\begin{tabular}{|l|c|c|l|}
\hline Inlet parameters & Lower value & Higher value & Units \\
\hline $\boldsymbol{F}$ & 0.00001 & 0.00005 & $\mathrm{~L} / \mathrm{s}$ \\
\hline $\boldsymbol{t}_{\boldsymbol{a} \text { dd }}$ & 1000 & 3000 & $\mathrm{~S}$ \\
\hline $\boldsymbol{U A}$ & 3 & 6 & $\mathrm{~W} / \mathrm{K}$ \\
\hline $\boldsymbol{T}_{\text {Feed }}$ & 293.15 & 308.15 & $\mathrm{~K}$ \\
\hline $\boldsymbol{T}_{\boldsymbol{j}}$ & 333.15 & 344.15 & $\mathrm{~K}$ \\
\hline [HP]o & 8 & 11 & $\mathrm{~mol} / \mathrm{L}$ \\
\hline
\end{tabular}


For this reaction system, it is essential to:

-avoid high reaction temperature that could trigger secondary reactions,

-avoid that the reaction temperature reached its maximum value too fast,

-favor the maximum concentration of epoxide group,

-favor the shorter time to reach the maximum concentration in epoxide group.

For this reason, the four responses $\left(T_{R, \max }, t_{T R, \max }, C_{E p, \max }, t_{C E p, \max }\right)$ were selected.

Explicit relationships are expressed as

$$
\begin{aligned}
& \text { Response }=\text { Constant }+\mathrm{X} 1 \cdot \mathrm{F}+\mathrm{X} 2 \cdot t_{\text {add }}+\mathrm{X} 3 \cdot \mathrm{UA}+\mathrm{X} 4 \cdot \mathrm{T}_{\text {feed }}+\mathrm{X} 5 \cdot \mathrm{Tj}+\mathrm{X} 6 \cdot[\mathrm{HP}]_{0}+\mathrm{X} 7 \cdot \mathrm{F}^{2} \\
&+\mathrm{X} 8 \cdot \mathrm{F} \cdot t_{\text {add }}+\mathrm{X} 9 \cdot \mathrm{F} \cdot \mathrm{UA}+\mathrm{X} 10 \cdot \mathrm{F} \cdot \mathrm{T}_{\text {feed }}+\mathrm{X} 11 \cdot \mathrm{F} \cdot \mathrm{Tj}+\mathrm{X} 12 \cdot \mathrm{F} \cdot[\mathrm{HP}]_{0}+\mathrm{X} 13 \\
& \cdot t_{\text {add }}{ }^{2}+\mathrm{X} 14 \cdot t_{\text {add }} \cdot \mathrm{UA}+\mathrm{X} 15 \cdot t_{\text {add }} \cdot \mathrm{T}_{\text {feed }}+\mathrm{X} 16 \cdot t_{\text {add }} \cdot \mathrm{Tj}+\mathrm{X} 17 \cdot t_{\text {add }} \cdot[\mathrm{HP}]_{0} \\
&+\mathrm{X} 18 \cdot \mathrm{UA}{ }^{2}+\mathrm{X} 19 \cdot \mathrm{UA} \cdot \mathrm{T}_{\text {feed }}+\mathrm{X} 20 \cdot \mathrm{UA} \cdot \mathrm{Tj}+\mathrm{X} 21 \cdot \mathrm{UA} \cdot[\mathrm{HP}]_{0}+\mathrm{X} 22 \cdot \mathrm{T}_{\text {feed }}{ }^{2} \\
&+\mathrm{X} 23 \cdot \mathrm{T}_{\text {feed }} \cdot \mathrm{Tj}+\mathrm{X} 24 \cdot \mathrm{T}_{\text {feed }} \cdot[\mathrm{HP}]_{0}+\mathrm{X} 25 \cdot \mathrm{Tj}^{2}+\mathrm{X} 26 \cdot \mathrm{Tj} \cdot[\mathrm{HP}]_{0}+\mathrm{X} 27 \cdot[\mathrm{HP}]_{0}{ }^{2}
\end{aligned}
$$

where the responses are $T_{R, \max }(\mathrm{K}), t_{T R, \max }(\mathrm{s}), C_{E p, \max }(\mathrm{mol} / \mathrm{L})$ and $t_{C E p, \max }(\mathrm{s}) ; \mathrm{X} 1, \ldots, \mathrm{X} 27$ are the regression coefficients.

The reliabilty of the explicit relationships were evaluated by the coefficients of determination $R_{\text {Response }}^{2}$

$R_{\text {Response }}^{2}=1-\frac{\left.\sum \text { (Response }_{\text {Simulation }}-\text { Response }_{\text {LSM }}\right)^{2}}{\sum\left(\text { Response }_{\text {Simulation }}-\overline{\text { Response }}_{\text {Simulation }}\right)^{2}}$

where, $\overline{\text { Response }}_{\text {Simulation }}$ is the mean of the simulated response. 
The regression analysis was performed for each response by a set of numerical data ( 3000 numerical experiments), and then a validation stage was carried out by another set of numerical data (100 numerical data). 


\subsection{Safety analysis: $T_{R, \max }$ and $t_{T R, \max }$.}

Table 2 shows the values of the coefficient for $T_{R, \max }$ and $t_{T R, \max }$ responses. For the maximum reaction temperature $T_{R, \max }$, the coefficient of determination was found to be 0.969 for the regression analysis and 0.934 for the validation stage. Thus, one can conclude that the explicit model developed for this response is highly reliable. This observation was confirmed by the parity plot (for regression and validation) (Figure 3). For the time to reach the maximum reaction temperature, i.e., $t_{T R \text {,max }}$, the determination coefficients are slightly lower: 0.939 for the regression and 0.894 for the validation.

Figure 4 shows the parity plot for this response including the regression and validation stages.

Table 2. Coefficient values for explicit expression of $T_{R, \max }(\mathrm{K})$ and $t_{T R, \max }(\mathrm{s})$.

\begin{tabular}{|c|c|c|c|}
\hline Coefficients & Input parameters and units & $T_{R, \max }(\mathrm{K})$ & $t_{T R, \max }(\mathrm{s})$ \\
\hline Constant & - & $-3.624 \mathrm{E}+03$ & $2.508 \mathrm{E}+05$ \\
\hline $\mathrm{X} 1$ & $F(\mathrm{~L} / \mathrm{s})$ & $1.523 \mathrm{E}+07$ & $-4.629 \mathrm{E}+08$ \\
\hline $\mathrm{X} 2$ & $t_{\text {add }}(\mathrm{s})$ & $2.375 \mathrm{E}-01$ & 4.927E+00 \\
\hline $\mathrm{X} 3$ & $U A(\mathrm{~W} / \mathrm{K})$ & $-1.152 \mathrm{E}+02$ & $3.507 \mathrm{E}+02$ \\
\hline $\mathrm{X} 4$ & $T_{\text {feed }}(\mathrm{K})$ & $-9.821 \mathrm{E}-02$ & $-6.433 \mathrm{E}+00$ \\
\hline$\times 5$ & $T j(\mathrm{~K})$ & $1.915 \mathrm{E}+01$ & $-1.395 \mathrm{E}+03$ \\
\hline $\mathrm{X} 6$ & $H P(\mathrm{~mol} / \mathrm{L})$ & $9.151 \mathrm{E}+01$ & $-4.759 \mathrm{E}+02$ \\
\hline $\mathrm{X} 7$ & $F^{2}\left(\mathrm{~L}^{2} / \mathrm{s}^{2}\right)$ & $-1.415 \mathrm{E}+10$ & $6.361 \mathrm{E}+11$ \\
\hline $\mathrm{x} 8$ & $F(\mathrm{~L} / \mathrm{s}) \cdot t_{a d d}(\mathrm{~s})$ & $-1.530 \mathrm{E}+02$ & $-4.218 \mathrm{E}+03$ \\
\hline $\mathrm{X} 9$ & $\mathrm{~F}(\mathrm{~L} / \mathrm{s}) \cdot \mathrm{UA}(\mathrm{W} / \mathrm{K})$ & $-4.197 \mathrm{E}+05$ & $-3.445 \mathrm{E}+05$ \\
\hline $\mathrm{X} 10$ & $F(L / s) \cdot T_{\text {feed }}(K)$ & $5.498 \mathrm{E}+00$ & $-5.422 \mathrm{E}+02$ \\
\hline
\end{tabular}




\begin{tabular}{|c|c|c|c|}
\hline $\mathrm{X} 11$ & $\mathrm{~F}(\mathrm{~L} / \mathrm{s}) \cdot \mathrm{Tj}(\mathrm{K})$ & $-3.712 \mathrm{E}+04$ & $1.208 \mathrm{E}+06$ \\
\hline $\mathrm{X} 12$ & $\mathrm{~F}(\mathrm{~L} / \mathrm{s}) \cdot \mathrm{HP}(\mathrm{mol} / \mathrm{L})$ & $1.757 \mathrm{E}+05$ & $5.928 \mathrm{E}+05$ \\
\hline $\mathrm{X} 13$ & $\operatorname{tadd}^{2}\left(s^{2}\right)$ & $-2.664 \mathrm{E}-06$ & $-5.155 E-05$ \\
\hline $\mathrm{X} 14$ & $\operatorname{tadd}(s) \cdot \mathrm{UA}(\mathrm{W} / \mathrm{K})$ & $-7.359 E-04$ & 3.588E-02 \\
\hline $\mathrm{X} 15$ & $\operatorname{tadd}(s) \cdot \mathrm{T}_{\text {feed }}(\mathrm{K})$ & $-5.698 \mathrm{E}-07$ & 4.000E-06 \\
\hline $\mathrm{X} 16$ & $\operatorname{tadd}(s) \cdot \operatorname{Tj}(\mathrm{K})$ & $-6.279 \mathrm{E}-04$ & $-1.270 \mathrm{E}-02$ \\
\hline $\mathrm{X} 17$ & $\operatorname{tadd}(s) \cdot \mathrm{HP}(\mathrm{mol} / \mathrm{L})$ & $-2.715 E-04$ & $-2.609 E-02$ \\
\hline $\mathrm{X} 18$ & $\mathrm{UA}^{2}\left(\mathrm{~W}^{2} / \mathrm{K}^{2}\right)$ & $3.397 \mathrm{E}+00$ & $-1.024 \mathrm{E}+01$ \\
\hline $\mathrm{X} 19$ & $\mathrm{UA}(\mathrm{W} / \mathrm{K}) \cdot \mathrm{T}_{\text {feed }}(\mathrm{K})$ & $1.224 \mathrm{E}-03$ & 6.953E-03 \\
\hline X20 & $\mathrm{UA}(\mathrm{W} / \mathrm{K}) \cdot \mathrm{Tj}(\mathrm{K})$ & $2.934 \mathrm{E}-01$ & $-1.134 \mathrm{E}+00$ \\
\hline $\mathrm{X} 21$ & $\mathrm{UA}(\mathrm{W} / \mathrm{K}) \cdot \mathrm{HP}(\mathrm{mol} / \mathrm{L})$ & $-1.824 \mathrm{E}+00$ & $6.955 E+00$ \\
\hline $\mathrm{X} 22$ & $T_{\text {feed }}{ }^{2}$ & $1.485 \mathrm{E}-05$ & $-8.657 \mathrm{E}-05$ \\
\hline $\mathrm{X} 23$ & $\mathrm{~T}_{\text {feed }}(K) \cdot \mathrm{Tj}(\mathrm{K})$ & $2.552 \mathrm{E}-04$ & $1.791 \mathrm{E}-02$ \\
\hline X24 & $\mathrm{T}_{\text {feed }}(K) \cdot \mathrm{HP}(\mathrm{mol} / \mathrm{L})$ & $-1.168 \mathrm{E}-04$ & 2.576E-02 \\
\hline X25 & $\mathrm{Tj}^{2}\left(\mathrm{~K}^{2}\right)$ & $-2.236 \mathrm{E}-02$ & $1.954 \mathrm{E}+00$ \\
\hline X26 & $\mathrm{Tj}(K) \cdot \mathrm{HP}(\mathrm{mol} / \mathrm{L})$ & $-2.442 \mathrm{E}-01$ & $1.104 \mathrm{E}+00$ \\
\hline $\mathrm{X} 27$ & $\mathrm{HP}^{2}\left(\mathrm{~mol}^{2} / \mathrm{L}^{2}\right)$ & 7.309E-02 & $2.032 \mathrm{E}+00$ \\
\hline
\end{tabular}




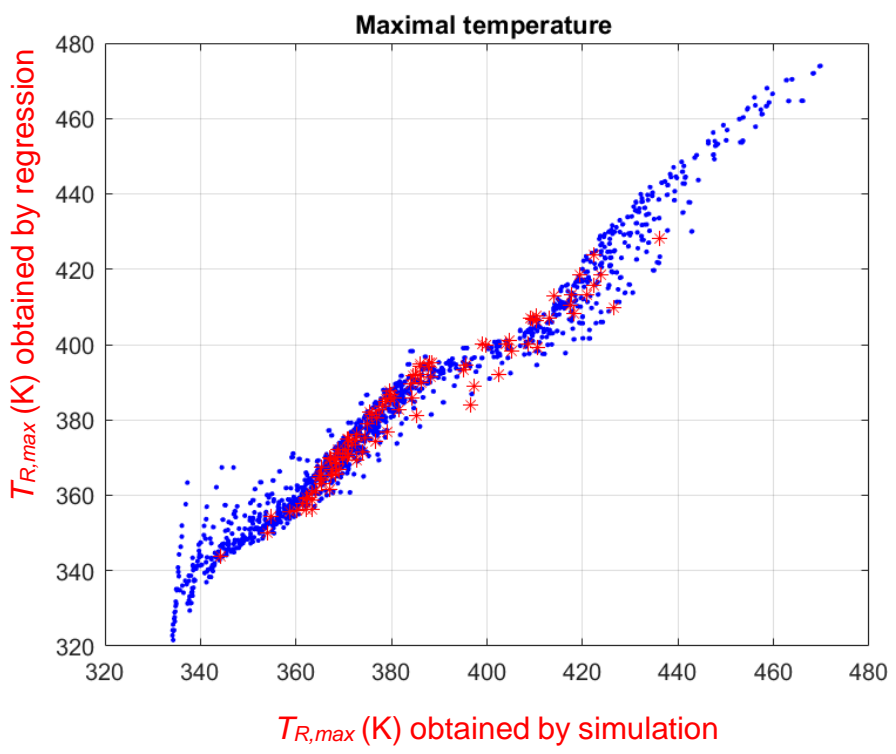

Figure 3. Parity plot for $T_{R, \max }$ (regression: blue dot and validation: red star): maximal temperature values $(\mathrm{K})$ resulting from the numerical simulation are reported in $\mathrm{X}$ and maximal temperature values $(\mathrm{K})$ resulting from the second order explicit Equation 21 are reported in $\mathrm{Y}$.

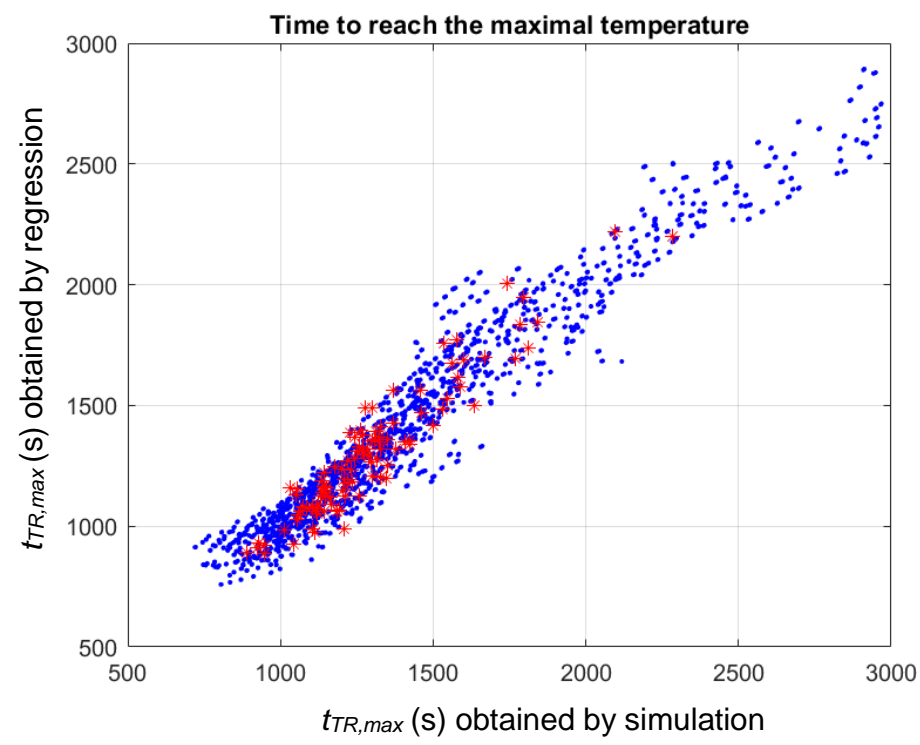

Figure 4. Parity plot for $t_{T R, \max }$ (regression: blue dot and validation: red star): time values (s) resulting from the numerical simulation are reported in $\mathrm{X}$ and time values (s) resulting from the second order explicit Equation 21 are reported in $\mathrm{Y}$. 


\subsection{Performance analysis: $C_{E p, \max }$ and $t_{C E P, \max }$}

Table 3 shows the values of the coefficient for $C_{E p, \max }$ and $t_{C E p, \max }$ responses. For the maximum concentration of epoxide, $C_{E p, \max }$, the coefficient of determination was found to be 0.868 for the regression analysis and 0.872 for the validation stage. Thus, one can conclude that the reliability of the explicit model developed for this response is medium. This observation was confirmed by the parity plot (for regression and validation, see Figures 5 and 6 ). In particular, for the time to reach the maximum concentration, i.e., $t_{C E p, \max }$, the determination coefficients are lower: 0.840 for the regression and 0.807 for the validation. The prediction of these parameters is difficult, because the epoxide concentration reaches a plateau making difficult to estimate accurately both parameters (Figure 9).

Table 3. Coefficient values for explicit expression of $C_{E p, \max }(\mathrm{mol} / \mathrm{L})$ and tcEp,max $(\mathrm{s})$.

\begin{tabular}{|c|c|l|l|}
\hline Coefficients & Input parameters and units & $\mathrm{C}_{\mathrm{Ep}, \max }(\mathrm{mol} / \mathrm{L})$ & $\mathrm{t}_{\mathrm{CEp}, \mathrm{max}}(\mathrm{s})$ \\
\hline Constant & - & $-1.147 \mathrm{E}+02$ & $1.326 \mathrm{E}+07$ \\
\hline $\mathrm{X} 1$ & $F(\mathrm{~L} / \mathrm{s})$ & $1.221 \mathrm{E}+05$ & $-2.822 \mathrm{E}+10$ \\
\hline $\mathrm{X} 2$ & $t_{\text {add }}(\mathrm{s})$ & $-2.242 \mathrm{E}-03$ & $-4.349 \mathrm{E}+02$ \\
\hline $\mathrm{X} 3$ & $U A(\mathrm{~W} / \mathrm{K})$ & $6.262 \mathrm{E}-01$ & $3.779 \mathrm{E}+04$ \\
\hline $\mathrm{X} 4$ & $T$ feed $(\mathrm{K})$ & $3.440 \mathrm{E}-03$ & $3.708 \mathrm{E}+00$ \\
\hline$X 5$ & $T j(\mathrm{~K})$ & $7.480 \mathrm{E}-01$ & $-7.022 \mathrm{E}+04$ \\
\hline$X 6$ & $H P(\mathrm{~mol} / \mathrm{L})$ & $-9.380 \mathrm{E}-01$ & $-7.851 \mathrm{E}+04$ \\
\hline$X 7$ & $F^{2}\left(\mathrm{~L} 2 / s^{2}\right)$ & $4.114 \mathrm{E}+08$ & $2.293 \mathrm{E}+13$ \\
\hline
\end{tabular}




\begin{tabular}{|c|c|c|c|}
\hline $\mathrm{X} 8$ & $F(\mathrm{~L} / \mathrm{s}) \cdot t_{a d d}(\mathrm{~s})$ & $-1.444 \mathrm{E}+00$ & $4.956 \mathrm{E}+05$ \\
\hline X9 & $F(L / s) \cdot U A(W / K)$ & $9.733 \mathrm{E}+03$ & $-4.906 \mathrm{E}+06$ \\
\hline $\mathrm{X} 10$ & $\mathrm{~F}(\mathrm{~L} / \mathrm{s}) \cdot \mathrm{T}_{\text {feed }}(\mathrm{K})$ & $-5.156 \mathrm{E}+00$ & $2.431 E+04$ \\
\hline $\mathrm{X} 11$ & $\mathrm{~F}(\mathrm{~L} / \mathrm{s}) \cdot \mathrm{Tj}(\mathrm{K})$ & $-5.316 \mathrm{E}+02$ & $7.268 \mathrm{E}+07$ \\
\hline $\mathrm{X} 12$ & $\mathrm{~F}(\mathrm{~L} / \mathrm{s}) \cdot \mathrm{HP}(\mathrm{mol} / \mathrm{L})$ & $-4.576 \mathrm{E}+03$ & 7.087E+07 \\
\hline $\mathrm{X} 13$ & $\operatorname{tadd}^{2}\left(s^{2}\right)$ & 6.926E-08 & $5.484 \mathrm{E}-03$ \\
\hline $\mathrm{X} 14$ & $\operatorname{tadd}(s) \cdot \mathrm{UA}(\mathrm{W} / \mathrm{K})$ & $-1.700 \mathrm{E}-05$ & $-5.187 E-01$ \\
\hline $\mathrm{X} 15$ & $\operatorname{tadd}(s) \cdot \mathrm{T}_{\text {feed }}(\mathrm{K})$ & $-3.238 E-08$ & $-4.159 \mathrm{E}-04$ \\
\hline $\mathrm{X} 16$ & $\operatorname{tadd}(s) \cdot \operatorname{Tj}(\mathrm{K})$ & 5.559E-06 & $1.127 \mathrm{E}+00$ \\
\hline $\mathrm{X} 17$ & $\operatorname{tadd}(s) \cdot \mathrm{HP}(\mathrm{mol} / \mathrm{L})$ & $9.630 \mathrm{E}-06$ & $1.155 E+00$ \\
\hline $\mathrm{X} 18$ & $\mathrm{UA}^{2}\left(\mathrm{~W}^{2} / \mathrm{K}^{2}\right)$ & $-1.829 E-02$ & $-1.298 \mathrm{E}+02$ \\
\hline $\mathrm{X} 19$ & $\mathrm{UA}(\mathrm{W} / \mathrm{K}) \cdot \mathrm{T}_{\text {feed }}(\mathrm{K})$ & $-1.414 \mathrm{E}-05$ & $-2.216 \mathrm{E}-01$ \\
\hline X20 & $\mathrm{UA}(\mathrm{W} / \mathrm{K}) \cdot \mathrm{Tj}(\mathrm{K})$ & $-7.747 E-04$ & $-9.918 \mathrm{E}+01$ \\
\hline $\mathrm{X} 21$ & $\mathrm{UA}(\mathrm{W} / \mathrm{K}) \cdot \mathrm{HP}(\mathrm{mol} / \mathrm{L})$ & $-3.032 \mathrm{E}-03$ & $-7.041 \mathrm{E}+01$ \\
\hline X22 & $\mathrm{T}_{\text {feed }}{ }^{2}$ & 5.417E-07 & $1.665 \mathrm{E}-02$ \\
\hline $\mathrm{X} 23$ & $\mathrm{~T}_{\text {feed }}(K) \cdot \mathrm{Tj}(\mathrm{K})$ & $-1.064 \mathrm{E}-05$ & $-1.555 E-02$ \\
\hline X24 & $\mathrm{T}_{\text {feed }}(K) \cdot \mathrm{HP}(\mathrm{mol} / \mathrm{L})$ & 2.893E-06 & $-7.726 \mathrm{E}-01$ \\
\hline X25 & $\mathrm{Tj}^{2}\left(\mathrm{~K}^{2}\right)$ & $-1.185 E-03$ & $9.323 E+01$ \\
\hline $\mathrm{X} 26$ & $\mathrm{Tj}(K) \cdot \mathrm{HP}(\mathrm{mol} / \mathrm{L})$ & 2.972E-03 & $2.004 \mathrm{E}+02$ \\
\hline $\mathrm{X} 27$ & $\mathrm{HP}^{2}\left(\mathrm{~mol}^{2} / \mathrm{L}^{2}\right)$ & $-2.624 \mathrm{E}-03$ & $2.635 \mathrm{E}+02$ \\
\hline
\end{tabular}




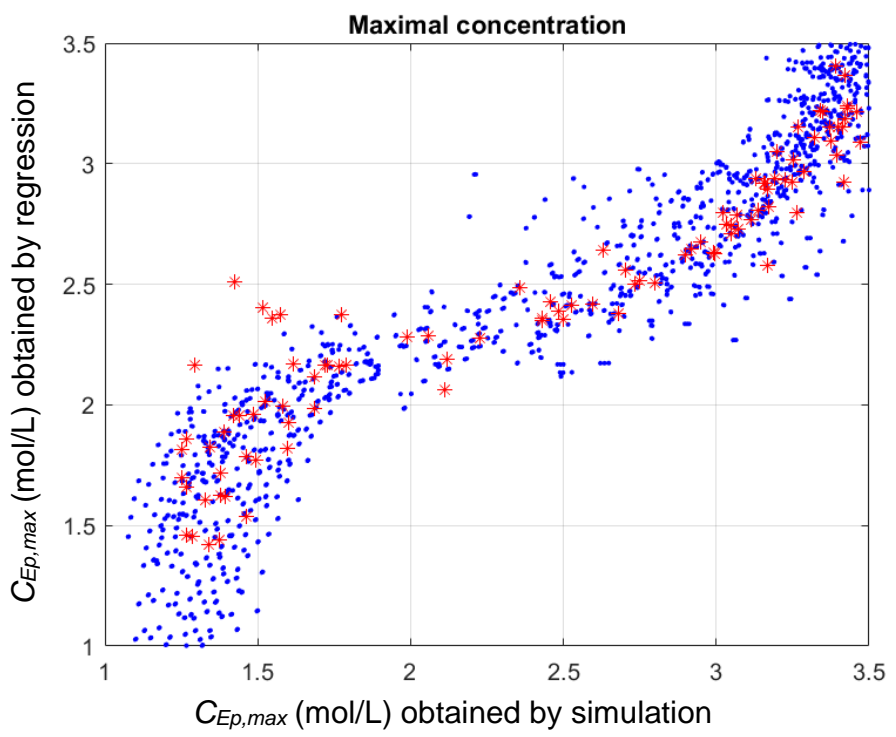

Figure 5. Parity plot for $C_{E p, \max }$ (regression: blue dot and validation: red star): maximal concentration values $(\mathrm{mol} / \mathrm{L})$ resulting from the numerical simulation are reported in $\mathrm{X}$ and maximal concentration values $(\mathrm{mol} / \mathrm{L})$ resulting from the second order explicit Equation 21 are reported in $\mathrm{Y}$.

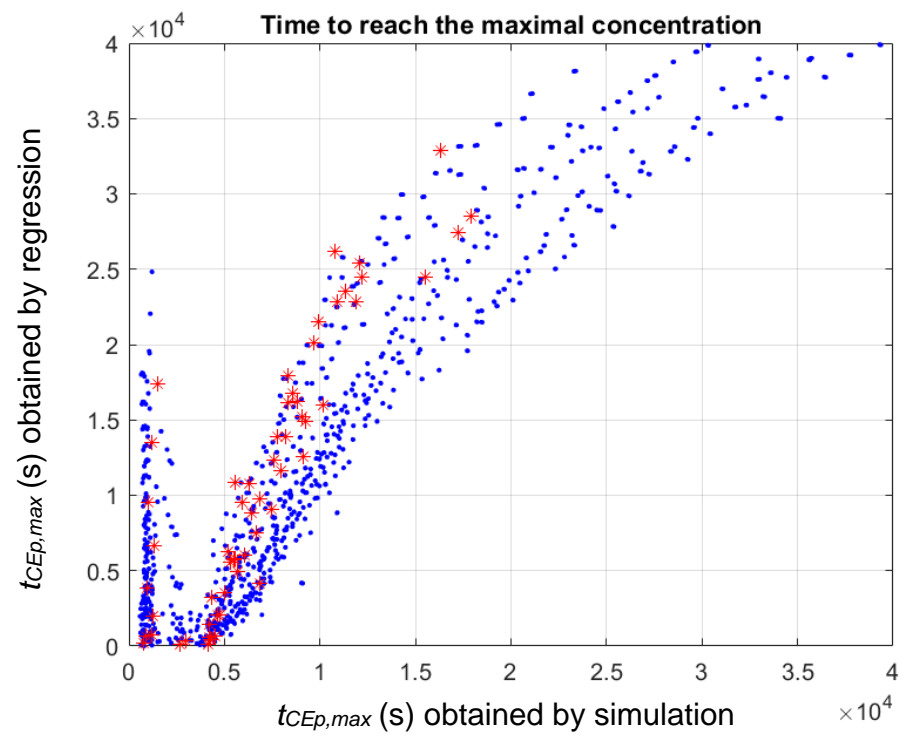

Figure 6. Parity plot for $t_{C E p, \max }$ (regression: blue dot and validation: red star): time values (s) resulting from the numerical simulation are reported in $\mathrm{X}$ and time values (s) resulting from the second order explicit Equation 21 are reported in $\mathrm{Y}$. 


\subsection{Error distribution}

Figure 7 reports the histograms of the errors resulting from the use of the second order explicit Equation 21 with respect to the numerical simulation. Concerning the parameters $T_{R, \max }$ and $t_{T R, \max }$ a near Gaussian centered distribution of the errors is obtained whereas the distribution for $C_{E p, \max }$ and $t_{C E p, \max }$ is clearly non Gaussian and non symetric. These distributions confirm that a second order regression is suitable to represent the parameters $T_{R, \max }$ and $t_{T R, \max }$, but that such a regression poorly represents $C_{E p, \max }$ and $t_{C E p, \max }$.
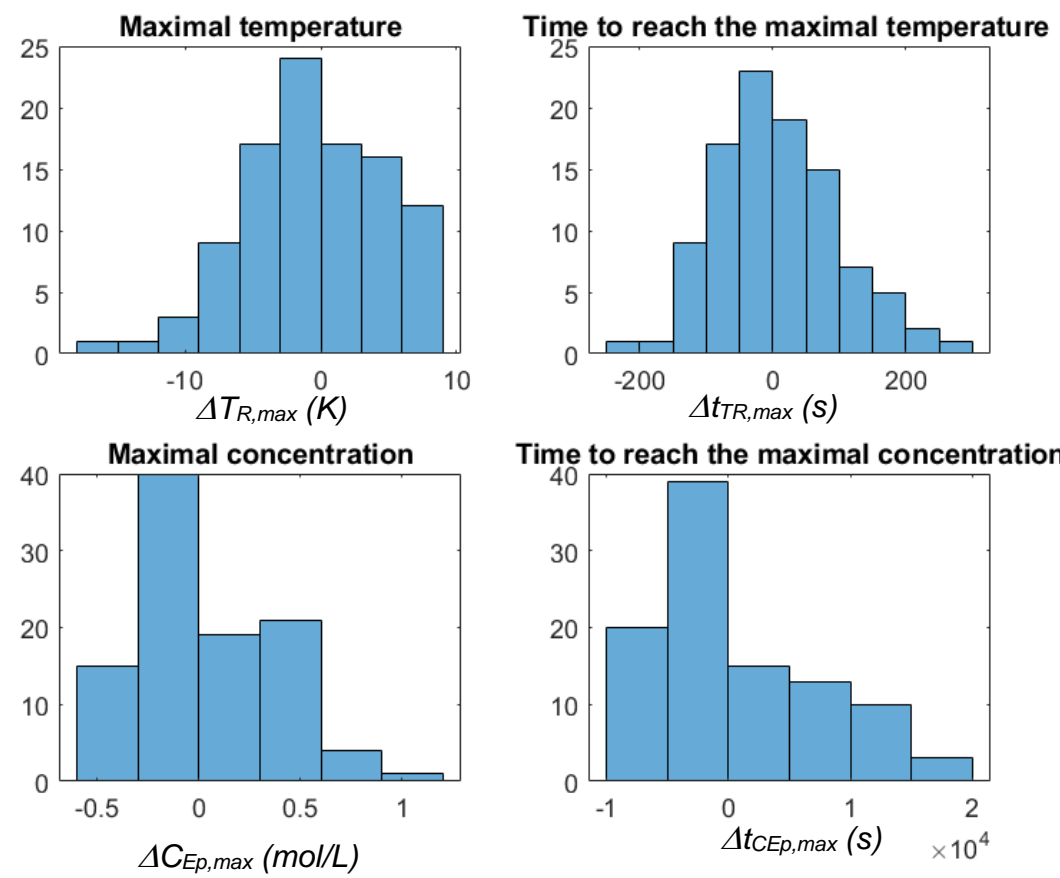

Figure 7. Error distribution $\Delta T_{R, \max }, \Delta t_{T R, \max }, \Delta C_{E p, \max }$ and $\Delta t_{C E p, \max }$ for the 4 responses $T_{R, \max }$, $t_{T R, \max }, C_{E p, \max }$ and $t_{C E p, \max }(\mathrm{X}$-axis are in $\mathrm{K}$ for the maximal temperature error, in $\mathrm{mol} / \mathrm{L}$ for the maximal concentration error and in s for the two characteristic time errors).

\subsection{Pareto chart}

In order to find the best values of the inlet parameters, the problem can be formulated as a multicriteria optimization problem. In particular, two criteria can be defined and optimized. A performance indicator is defined by Equation 23:

$C_{P}=t_{C E P \max } / C_{E p m}$ 
A safety indicator is defined by Equation 24:

$C_{S}=T_{R \max } / t_{T R \max }$

Both indicators have to be minimized to ensure both a maximal yield and a maximal safety level. For this purpose, and thanks to the numerical simulator that model the considered reaction, a Pareto chart is computed with respect to $\mathrm{Cs}_{\mathrm{s}}$ and $\mathrm{C}$. Figure 8 plots the whole domain of double criteria $\left(C_{S}, C_{P}\right)$ for the range of the inlet parameters reported in Table 1 as the Pareto border (red points). Figure 6 helps to find the optimum operating conditions from a double safety and production perspective.

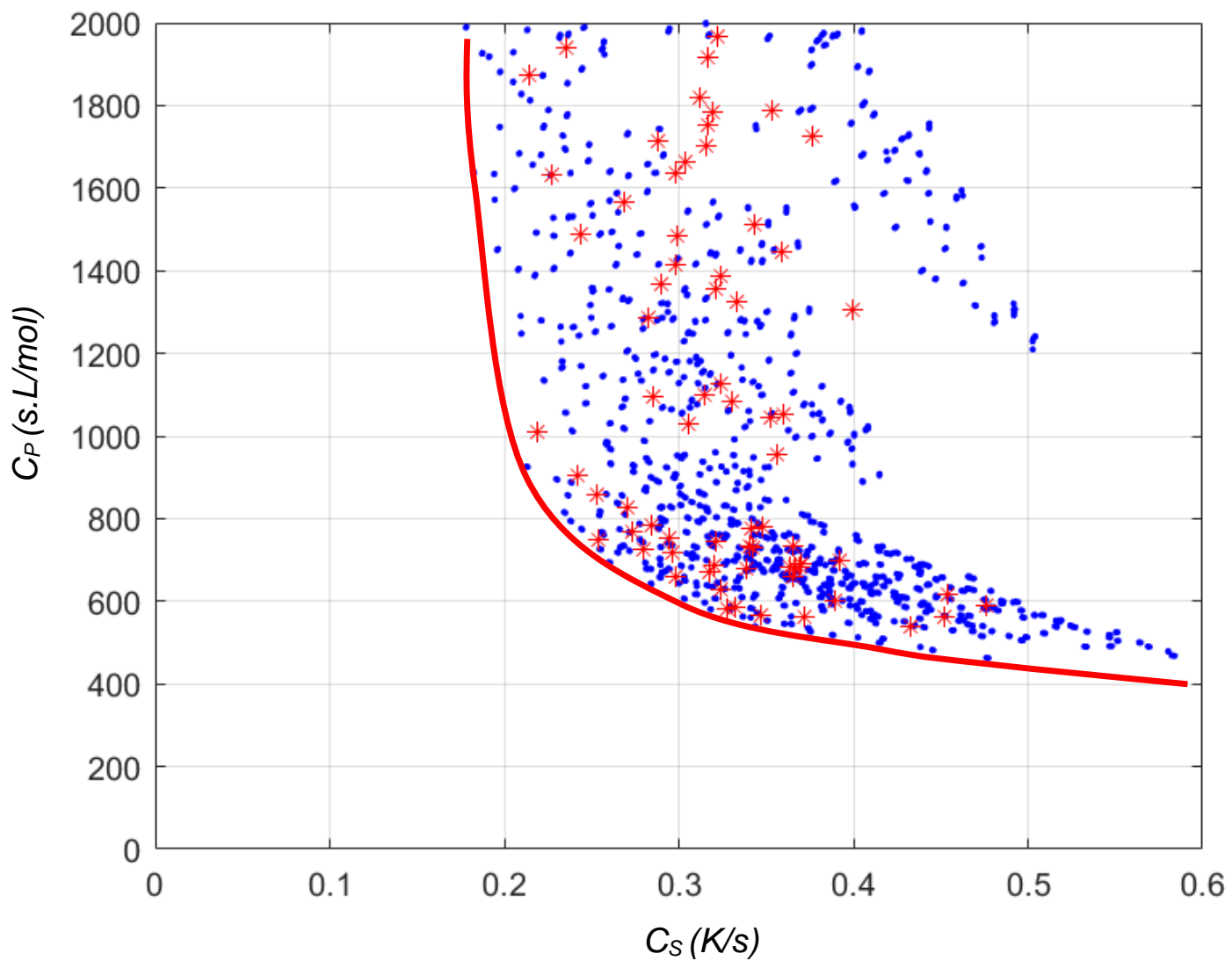

Figure 8. Pareto domain: safety $\left(\mathrm{C}_{\mathrm{s}}\right)$ versus performance $\left(\mathrm{C}_{\mathrm{P}}\right)$. 


\subsection{Laboratory validation}

To verify the validty of the explicit models, laboratory experiments were performed with the experimental conditions displayed by Table 4. The uncertainty measurement for epoxide concentration was found to be lower than $2 \%$, and the accuracy of the temperature was of $0.1 \mathrm{~K}$. The relative error was used to evaluate the accuracy of the explicit models.

$$
\text { Absolute Relative error }(\%)=\frac{\mid \text { Experimental-Simulation }(\text { Eq.14) } \mid}{\text { Experimental }} * 100
$$

Table 4. Relative errors between LSM and laboratory data.

\begin{tabular}{|c|c|c|c|c|c|c|c|c|c|c|}
\hline \multirow{2}{*}{ Run } & \multicolumn{5}{|c|}{ Operating conditions (Inlet parameters) } & \multicolumn{5}{c|}{ Relative error (\%) } \\
\hline & $F$ & $t_{\text {add }}$ & $U A$ & $T_{\text {feed }}$ & $T_{j}$ & $H P$ & $T_{R, \max }$ & $t_{T R, \max }$ & $C_{E p, \max }$ & $t_{C E p, \max }$ \\
& $\mathrm{L} / \mathrm{s}$ & $\mathrm{S}$ & $\mathrm{W} / \mathrm{K}$ & $\mathrm{K}$ & $\mathrm{K}$ & $\mathrm{mol} / \mathrm{L}$ & $\mathrm{K}$ & $\mathrm{s}$ & $\mathrm{mol} / \mathrm{L}$ & $\mathrm{s}$ \\
\hline 1 & $1.2577 \mathrm{E}-05$ & 3000 & 4.7 & 295.19 & 343.12 & 8.57 & 3.28 & 0.54 & 5.60 & 35.12 \\
\hline 2 & $2.5153 \mathrm{E}-05$ & 1500 & 4.5 & 295.17 & 334.14 & 8.5 & 3.99 & 20.51 & 7.07 & 580.32 \\
\hline 3 & $3.1441 \mathrm{E}-05$ & 1500 & 4.3 & 295.11 & 343.68 & 8.62 & 1.68 & 5.54 & 32.58 & 135.25 \\
\hline 4 & $3.1441 \mathrm{E}-05$ & 1500 & 4.4 & 297.25 & 344.05 & 8.35 & 0.74 & 0.37 & 29.24 & 128.58 \\
\hline 5 & $3.1441 \mathrm{E}-05$ & 1500 & 4.4 & 297.21 & 344.29 & 10.16 & 3.82 & 23.36 & 36.72 & 263.51 \\
\hline
\end{tabular}

Table 4 shows that the explicit models is validated experimentally for the responses $T_{R, \max }, t_{T R, \max }$ and

$C_{E p, \max }$. However, the explicit model for the time to reach the maximum concentration is not accurate.

As mentioned earlier, the epoxide concentration reaches a plateau and the ring opening reaction is slow under the studied operating conditions. Figure 9 shows the experimental values for the epoxide concentration and reaction temperature for Run 1. One can notice that the epoxide concentration reaches a plateau making difficult to find the value $t_{C E p, \max }$. 


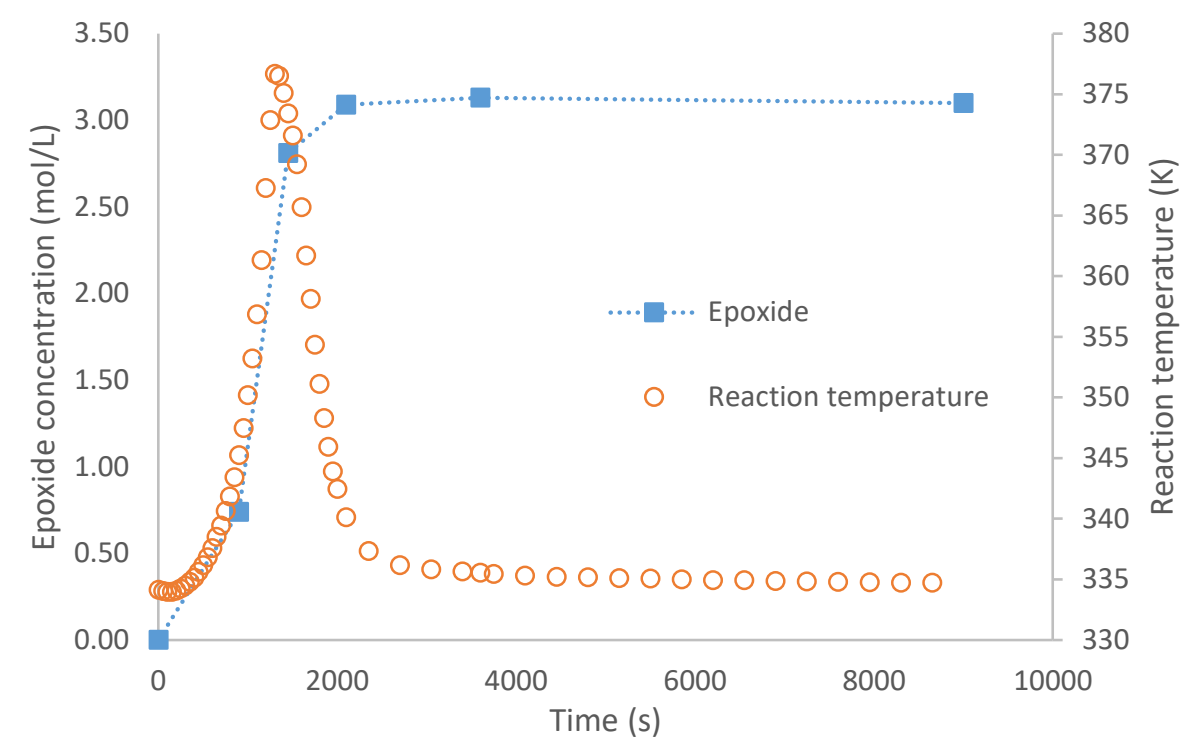

Figure 9. Experimental epoxide concentration and reaction temperature.

Despite the fact the explicit models for the responses have not the same accuracy, the simultaneous use of the four explicit models is helpful to find near-optimum operating conditions towards performance and safety. The use of such an approach saves time and is tractable for complex reactions (instead of the ODEs resolution). 


\section{Conclusions}

The influence of inlet parameters on thermal risk and production responses is complicated to determine. Indeed, the kinetic model, including the energy and material balance of a process, can be cumbersome. This complexity can be challenging to handle during on-site production, and one should find some explicit relationships and guidelines easy to apply to help the operator to understand the influence of inlet parameters on performance and safety.

This manuscript proposed such a study for the production of epoxidized vegetable oil under isoperibolic and semi-batch mode. The numerical design of experiments from the study of Zheng et al. (Zheng et al., 2016) was developed and a numerical simulator has been derived. The influence of six inlet parameters (volumetric flow rate, time of addition, global heat transfer coefficient, the temperature of feed, jacket temperature and initial concentration of hydrogen peroxide) was evaluated on four responses (maximum reaction temperature, maximum yield of epoxide, time to reach the maximum temperature and time to reach the maximum yield). Explicit mappings have been proposed for this purpose. It is important to stress on the fact that the explicit relationships developed in this work are only valid by using the values of inlet parameters displayed in Table 1 and by using a similar reactor system. It was also found that compromising values of these inlet parameters should be preferred in order to reach performing and safe operating conditions. A double performance / safety indicator was used to find such compromising values.

As a final conclusion, it is important to enhance that the main benefit of this approach is to propose a systematic and simple method that determines the influence of a set of inlet parameters on a set of output indicators. Such a tool can be further studied to develop a more advanced optimization stage. This approach can be used in industry for some complex systems to help the operators to reach a better understanding of the various aspects of the process under interest. This study can be considered as a first brick to develop explicit relationships for complex non-liner chemical system, and a further investigation of this work must be to study the limit of this method. 
Author Contributions: Conceptualization, S.Leveneur and J.-C.Buvat, D. Lefebvre; methodology software, T.Rigaux and N. Zora; validation, T.Rigaux, N. Zora, S.Leveneur and J.-C.Buvat; writingoriginal draft preparation, T.Rigaux, N. Zora, S.Leveneur and J.-C.Buvat; writing—review and editing, T.Rigaux, N. Zora, S.Leveneur, J.-C.Buvat and D. Lefebvre ; supervision, S.Leveneur and J.C.Buvat, D. Lefebvre.

Acknowledgments: The authors thank the Département de Maîtrise des Risques et Environnementaux.

Conflicts of Interest: The authors declare no conflict of interest. 


\section{Nomenclature}

$a$

A

$A^{\prime}$

$\overline{\mathrm{C}}_{\mathrm{P}}$

$\hat{\mathrm{C}}_{\mathrm{P}}$

Ea

$\Delta H_{R}$

Int

$K^{c}$

$K_{i}$

$K^{T}$

KWATER

$K_{F A}$

$K_{P F A}$

k

$k_{\text {decomp }}$

$m_{R}$

$N_{i}$

$\dot{\mathrm{n}}_{\mathrm{i}, \mathrm{aq}, \mathrm{in}}$

$n_{i, a q}$
$\frac{\mathrm{A} \prime}{\mathrm{V}_{\mathrm{T}}}\left[\mathrm{m}^{2} / \mathrm{L}\right]$

heat transfer area $\left[\mathrm{m}^{2}\right]$

interfacial area $\left[\mathrm{m}^{2}\right]$

constant-pressure heat capacity per mol [J/mol.K]

constant-pressure heat capacity per mass $[\mathrm{J} / \mathrm{g} \cdot \mathrm{K}]$

activation energy $[\mathrm{J} / \mathrm{mol}]$

reaction enthalpy $[\mathrm{J} / \mathrm{mol}]$

possible linoleic acid moiety intermediate detected by GC

equilibrium constant, based on concentrations

equilibrium molar ratio of compound $i$

thermodynamic equilibrium constant, based on activies

equilibrium molar ratio of water

equilibrium molar ratio of formic acid

equilibrium molar ratio of peroxyformic acid

rate constant

decomposition rate constant $\left[\mathrm{s}^{-1}\right]$

mass $[\mathrm{kg}]$

diffusion flux of the compound $i\left[\mathrm{~mol} / \mathrm{m}^{2} . \mathrm{s}\right]$

inlet molar flow of compound $i[\mathrm{~mol} / \mathrm{s}]$

amount of $i$ in the aqueous phase [mol] 


\begin{tabular}{|c|c|}
\hline$n_{i, o r g}$ & amount of $i$ in the organic phase [mol] \\
\hline$Q_{F A}$ & volumetric flow rate of formic acid [L/s] \\
\hline$Q_{a q}$ & volumetric flow rate of aqueous solution [L/s] \\
\hline$R$ & gas constant $[\mathrm{J} / \mathrm{K} . \mathrm{mol}]$ \\
\hline$r_{a q, j}$ & reaction rate $j$ in the aqueous phase [mol/L.s] \\
\hline$r_{\text {org }, j}$ & reaction rate $j$ in the organic phase [mol/L.s] \\
\hline$r_{i}$ & reaction rate [mol/L.s] \\
\hline$T_{R}$ & reaction temperature $[\mathrm{K}]$ \\
\hline$T$ & temperature $[\mathrm{K}]$ \\
\hline$U$ & overall heat transfer coefficient $\left[\mathrm{W} / \mathrm{m}^{2} . \mathrm{K}\right]$ \\
\hline$V_{a q}$ & volume of the aqueous phase [L] \\
\hline$V_{\text {org }}$ & volume of the organic phase [L] \\
\hline$V_{T}$ & total reaction volume [L] \\
\hline
\end{tabular}

Greek letters

$\alpha$

$\mathrm{V}_{\mathrm{aq}} / \mathrm{V}_{\mathrm{T}}$

$\beta$

$\frac{\mathrm{V}_{\text {org }}}{\mathrm{V}_{\mathrm{T}}}$

$\tau$

$\frac{\mathrm{V}_{\mathrm{T}}}{\mathrm{Q}_{\mathrm{aq}}}[\mathrm{S}]$

$\tau_{\mathrm{aq}}$

$\frac{V_{\mathrm{aq}}}{Q_{a q}}[\mathrm{~S}]$

$v_{i j}$ stoichiometric coefficient of compound $i$ in reaction $j$ 
Subscripts and superscripts

$\begin{array}{ll}\text { add } & \text { addition } \\ \text { ave } & \text { average } \\ \text { aq } & \text { aqueous phase } \\ \text { decomp } & \text { decomposition }\end{array}$

Deg by RO

organic products obtained by ring-opening reactions

Ep

epoxidized compounds

$\exp$

experimental data

feed

Feed

FAD

formic acid dissociation

i

component i

j

Reaction

org

organic phase

perh

Perhydrolysis

R

reaction mixture

ref

reference state

ROFA

ring-opening by formic acid

ROPFA

ring-opening by peroxyformic acid

ROW

ring-opening by water

RONuH

ring-opening by nucleophile compounds 


$\begin{array}{ll}\text { temp } & \text { Temperature } \\ \text { Abbreviations } & \text { Initial } \\ \text { C18:1 } & \text { oleic acid } \\ \text { C18:2 } & \text { linoleic acid } \\ \text { Int } & \text { linoleic acid intermediate } \\ \text { Ep } & \text { epoxidized products } \\ \text { FA } & \text { formic acid } \\ \text { HP } & \text { hydrogen peroxide } \\ \text { IN } & \text { iodine number } \\ \text { PFA } & \text { peroxyformic acid } \\ \text { W } & \text { water }\end{array}$

\section{References}

Adhvaryu, A., Erhan, S.Z., 2002. Epoxidized soybean oil as a potential source of high-temperature lubricants. Ind. Crops Prod. 15, 247-254. https://doi.org/10.1016/S0926-6690(01)00120-0

Aguilera, A.F., Tolvanen, P., Eränen, K., Leveneur, S., Salmi, T., 2016. Epoxidation of oleic acid under conventional heating and microwave radiation. Chem. Eng. Process. Process Intensif. 102, $70-$ 87. https://doi.org/10.1016/j.cep.2016.01.011

Aguilera, A.F., Tolvanen, P., Eränen, K., Wärnå, J., Leveneur, S., Marchant, T., Salmi, T., 2019a. 
Kinetic modelling of Prileschajew epoxidation of oleic acid under conventional heating and microwave irradiation. Chem. Eng. Sci. 199, 426-438. https://doi.org/10.1016/j.ces.2019.01.035

Aguilera, A.F., Tolvanen, P., Wärnå, J., Leveneur, S., Salmi, T., 2019b. Kinetics and reactor modelling of fatty acid epoxidation in the presence of heterogeneous catalyst. Chem. Eng. J. 375. https://doi.org/10.1016/j.cej.2019.121936

Arumugam, S., Sriram, G., Rajmohan, T., 2014. Multi-response optimization of epoxidation process parameters of rapeseed oil using response surface methodology (RSM)-based desirability analysis. Arab. J. Sci. Eng. 39, 2277-2287. https://doi.org/10.1007/s13369-013-0789-5

Cai, X., Zheng, J.L., Aguilera, A.F., Vernières-Hassimi, L., Tolvanen, P., Salmi, T., Leveneur, S., 2018. Influence of ring-opening reactions on the kinetics of cottonseed oil epoxidation. Int. J. Chem. Kinet. 50, 726-741. https://doi.org/10.1002/kin.21208

Campanella, A., Baltanás, M.A., 2007. Degradation of the oxirane ring of epoxidized vegetable oils in a liquid-liquid-solid heterogeneous reaction system. Chem. Eng. Process. Process Intensif. 46, 210-221. https://doi.org/10.1016/j.cep.2006.06.001

Campanella, A., Baltanás, M.A., 2006. Degradation of the oxirane ring of epoxidized vegetable oils in liquid-liquid heterogeneous reaction systems. Chem. Eng. J. 27, 67-76. https://doi.org/10.1016/j.cej.2006.01.010

Casson Moreno, V., Russo, V., Tesser, R., Di Serio, M., Salzano, E., 2017. Thermal risk in semibatch reactors: The epoxidation of soybean oil. Process Saf. Environ. Prot. 109, 529-537. https://doi.org/10.1016/j.psep.2017.05.001 
Cecilia, J.A., Plata, D.B., Saboya, R.M.A., de Luna, F.M.T., Cavalcante, C.L., Rodríguez-Castellón, E., 2020. An overview of the biolubricant production process: Challenges and future perspectives. Processes 8. https://doi.org/10.3390/pr8030257

Dakkoune, A., Vernières-Hassimi, L., Leveneur, S., Lefebvre, D., Estel, L., 2019. Analysis of thermal runaway events in French chemical industry. J. Loss Prev. Process Ind. 62. https://doi.org/10.1016/j.jp.2019.103938

Dakkoune, A., Vernières-Hassimi, L., Leveneur, S., Lefebvre, D., Estel, L., 2018. Risk analysis of French chemical industry. Saf. Sci. 105, 77-85. https://doi.org/10.1016/j.ssci.2018.02.003

Danov, S.M., Kazantsev, O.A., Esipovich, A.L., Belousov, A.S., Rogozhin, A.E., Kanakov, E.A., 2017. Recent advances in the field of selective epoxidation of vegetable oils and their derivatives: A review and perspective. Catal. Sci. Technol. 7, 3659-3675. https://doi.org/10.1039/c7cy00988g

de Haro, J.C., Izarra, I., Rodríguez, J.F., Pérez, Á., Carmona, M., 2016. Modelling the epoxidation reaction of grape seed oil by peracetic acid. J. Clean. Prod. 138, 70-76. https://doi.org/10.1016/j.jclepro.2016.05.015

Desroches, M., Escouvois, M., Auvergne, R., Caillol, S., Boutevin, B., 2012. From vegetable oils to polyurethanes: Synthetic routes to polyols and main industrial products. Polym. Rev. 52, 38-79. https://doi.org/10.1080/15583724.2011.640443

Goud, V. V., Patwardhan, A. V., Dinda, S., Pradhan, N.C., 2007a. Kinetics of epoxidation of jatropha oil with peroxyacetic and peroxyformic acid catalysed by acidic ion exchange resin. Chem. Eng. Sci. 62, 4065-4076. https://doi.org/10.1016/j.ces.2007.04.038 
Goud, V. V., Patwardhan, A. V., Dinda, S., Pradhan, N.C., 2007b. Epoxidation of karanja (Pongamia glabra) oil catalysed by acidic ion exchange resin. Eur. J. Lipid Sci. Technol. 109, 575-584. https://doi.org/10.1002/ejlt.200600298

Gurbanov, M.S., Chalabiev, C.A., Mamedov, B.A., Efendiev, A.A., 2005. Epoxidation of soybean oil in the course of cooxidation with hydrogen peroxide in the presence of propanoic acid and chlorinated KU-2 x 8 cation exchanger. Russ. J. Appl. Chem. 78, 1678-1682. https://doi.org/10.1007/s11167-005-0585-4

Hagström, A.E.V., Törnvall, U., Nordblad, M., Hatti-Kaul, R., Woodley, J.M., 2011. Chemo-enzymatic epoxidation-process options for improving biocatalytic productivity. Biotechnol. Prog. 27, 67-76. https://doi.org/10.1002/btpr.504

Harned, H.S., Embree, N.D., 1934. The Ionization Constant of Formic Acid from 0 to $60^{\circ}$. J. Am. Chem. Soc. 56, 1042-1044. https://doi.org/10.1021/ja01320a010

Hilker, I., Bothe, D., Prüss, J., Warnecke, H.J., 2001. Chemo-enzymatic epoxidation of unsaturated plant oils. Chem. Eng. Sci. 56, 427-432. https://doi.org/10.1016/S0009-2509(00)00245-1

Hosney, H., Nadiem, B., Ashour, I., Mustafa, I., El-Shibiny, A., 2018. Epoxidized vegetable oil and bio-based materials as PVC plasticizer. J. Appl. Polym. Sci. 135. https://doi.org/10.1002/app.46270

Jankovic, M., Sinadinovic-Fiser, S., 2004. Kinetic models of reaction systems for the in situ epoxidation of unsaturated fatty acid esters and triglycerides. Hem. Ind. 58, 569-576. https://doi.org/10.2298/hemind0412569j 
Köckritz, A., Martin, A., 2008. Oxidation of unsaturated fatty acid derivatives and vegetable oils. Eur. J. Lipid Sci. Technol. 110, 812-824. https://doi.org/10.1002/ejlt.200800042

Lathi, P.S., Mattiasson, B., 2007. Green approach for the preparation of biodegradable lubricant base stock from epoxidized vegetable oil. Appl. Catal. B Environ. 69, 207-212. https://doi.org/10.1016/j.apcatb.2006.06.016

Leveneur, S., 2017. Thermal Safety Assessment through the Concept of Structure-Reactivity: Application to Vegetable Oil Valorization. Org. Process Res. Dev. 21, 543-550. https://doi.org/10.1021/acs.oprd.6b00405

Leveneur, S., Estel, L., Crua, C., 2015. Thermal risk assessment of vegetable oil epoxidation. J. Therm. Anal. Calorim. 122, 795-804. https://doi.org/10.1007/s10973-015-4793-8

Leveneur, S., Ledoux, A., Estel, L., Taouk, B., Salmi, T., 2014a. Epoxidation of vegetable oils under microwave irradiation. Chem. Eng. Res. Des. 92, 1495-1502. https://doi.org/10.1016/j.cherd.2014.04.010

Leveneur, S., Pinchard, M., Rimbault, A., Safdari Shadloo, M., Meyer, T., 2018. Parameters affecting thermal risk through a kinetic model under adiabatic condition: Application to liquid-liquid reaction system. Thermochim. Acta 10-17. https://doi.org/10.1016/j.tca.2018.05.024

Leveneur, S., Salmi, T., Murzin, D.Y., Estel, L., Wärnå, J., Musakka, N., 2008. Kinetic study and modeling of peroxypropionic acid synthesis from propionic acid and hydrogen peroxide using homogeneous catalysts. Ind. Eng. Chem. Res. 47, 656-664. https://doi.org/10.1021/ie070670e 
Leveneur, S., Thönes, M., Hébert, J.P., Taouk, B., Salmi, T., 2012. From kinetic study to thermal safety assessment: Application to peroxyformic acid synthesis. Ind. Eng. Chem. Res. 51, 13999-14007. https://doi.org/10.1021/ie3017847

Leveneur, S., Wärnå, J., Salmi, T., Murzin, D.Y., Estel, L., 2009. Interaction of intrinsic kinetics and internal mass transfer in porous ion-exchange catalysts: Green synthesis of peroxycarboxylic acids. Chem. Eng. Sci. 64, 4101-4114. https://doi.org/10.1016/j.ces.2009.05.055

Leveneur, S., Zheng, J., Taouk, B., Burel, F., Wärnå, J., Salmi, T., 2014b. Interaction of thermal and kinetic parameters for a liquid-liquid reaction system: Application to vegetable oils epoxidation by peroxycarboxylic acid. J. Taiwan Inst. Chem. Eng. 45, 1449-1458. https://doi.org/10.1016/j.jtice.2014.01.015

Lu, H., Sun, S., Bi, Y., Yang, G., Ma, R., Yang, H., 2010. Enzymatic epoxidation of soybean oil methyl esters in the presence of free fatty acids. Eur. J. Lipid Sci. Technol. 112, 1101-1105. https://doi.org/10.1002/ejlt.201000041

Meshram, P.D., Puri, R.G., Patil, H. V., 2011. Epoxidation of wild safflower (Carthamus oxyacantha) oil with peroxy acid in presence of strongly acidic cation exchange resin IR-122 as catalyst. Int. J. ChemTech Res. 3, 1152-1163.

Milchert, E., Smagowicz, A., Lewandowski, G., 2010. Optimization of the epoxidation of rapeseed oil with peracetic acid. Org. Process Res. Dev. 14, 1094-1101. https://doi.org/10.1021/op900240p

Mungroo, R., Pradhan, N.C., Goud, V. V., Dalai, A.K., 2008. Epoxidation of canola oil with hydrogen peroxide catalyzed by acidic ion exchange resin. JAOCS, J. Am. Oil Chem. Soc. 85, 887-896. 
https://doi.org/10.1007/s11746-008-1277-z

Nohra, B., Candy, L., Blanco, J.F., Guerin, C., Raoul, Y., Mouloungui, Z., 2013. From petrochemical polyurethanes to biobased polyhydroxyurethanes. Macromolecules 46, 3771-3792. https://doi.org/10.1021/ma400197c

Orellana-Coca, C., Adlercreutz, D., Andersson, M.M., Mattiasson, B., Hatti-Kaul, R., 2005. Analysis of fatty acid epoxidation by high performance liquid chromatography coupled with evaporative light scattering detection and mass spectrometry. Chem. Phys. Lipids 135, 189-199. https://doi.org/10.1016/j.chemphyslip.2005.02.014

Orellana-Coca, C., Billakanti, J.M., Mattiasson, B., Hatti-Kaul, R., 2007. Lipase mediated simultaneous esterification and epoxidation of oleic acid for the production of

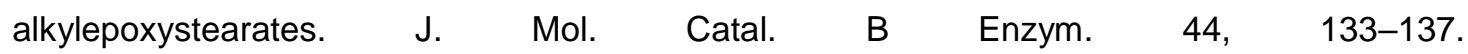
https://doi.org/10.1016/j.molcatb.2006.09.002

Osuna, Á.A.B., Mendivelso, L.A.B., 2010. Two-phase kinetic model for epoxidation of soybean oil. Ing. e Investig. 30, 188-196.

Parada Hernandez, N.L., Bonon, A.J., Bahú, J.O., Barbosa, M.I.R., Wolf Maciel, M.R., Filho, R.M., 2017. Epoxy monomers obtained from castor oil using a toxicity-free catalytic system. J. Mol. Catal. A Chem. 426, 550-556. https://doi.org/10.1016/j.molcata.2016.08.005

Pérez-Sena, W.Y., Cai, X., Kebir, N., Vernières-Hassimi, L., Serra, C., Salmi, T., Leveneur, S., 2018. Aminolysis of cyclic-carbonate vegetable oils as a non-isocyanate route for the synthesis of polyurethane: A kinetic and thermal study. Chem. Eng. J. 346, 271-280. 
https://doi.org/10.1016/j.cej.2018.04.028

Pérez-Sena, W.Y., Salmi, T., Estel, L., Leveneur, S., 2020. Thermal risk assessment for the epoxidation of linseed oil by classical Prisleschajew epoxidation and by direct epoxidation by H2O2 on alumina. J. Therm. Anal. Calorim. 140, 673-684. https://doi.org/10.1007/s10973-01908894-2

Piccolo, D., Vianello, C., Lorenzetti, A., Maschio, G., 2019. Epoxidation of soybean oil enhanced by microwave radiation. Chem. Eng. J. 377. https://doi.org/10.1016/j.cej.2018.10.050

Rakotondramaro, H., Wärnå, J., Estel, L., Salmi, T., Leveneur, S., 2016. Cooling and stirring failure for semi-batch reactor: Application to exothermic reactions in multiphase reactor. J. Loss Prev. Process Ind. 43, 147-157. https://doi.org/10.1016/j.jlp.2016.05.011

Rangarajan, B., Havey, A., Grulke, E.A., Culnan, P.D., 1995. Kinetic parameters of a two-phase model for in situ epoxidation of soybean oil. J. Am. Oil Chem. Soc. 72, 1161-1169. https://doi.org/10.1007/BF02540983

Rusch Gen Klaas, M., Warwel, S., 1999. Chemoenzymatic epoxidation of alkenes by dimethyl carbonate and hydrogen peroxide. Org. Lett. 1, 1025-1026. https://doi.org/10.1021/ol990803v

Santacesaria, E., Tesser, R., Di Serio, M., Turco, R., Russo, V., Verde, D., 2011. A biphasic model describing soybean oil epoxidation with $\mathrm{H} 2 \mathrm{O} 2$ in a fed-batch reactor. Chem. Eng. J. 173, 198209. https://doi.org/10.1016/j.cej.2011.05.018

Scotti, N., Ravasio, N., Psaro, R., Evangelisti, C., Dworakowska, S., Bogdal, D., Zaccheria, F., 2015. 
Copper mediated epoxidation of high oleic natural oils with a cumene-O2 system. Catal. Commun. 64, 80-85. https://doi.org/10.1016/j.catcom.2015.02.008

Sepulveda, J., Teixeira, S., Schuchardt, U., 2007. Alumina-catalyzed epoxidation of unsaturated fatty esters with hydrogen peroxide. Appl. Catal. A Gen. 318, 213-217. https://doi.org/10.1016/j.apcata.2006.11.004

Sinadinović-Fišer, S., Janković, M., Borota, O., 2012. Epoxidation of castor oil with peracetic acid formed in situ in the presence of an ion exchange resin. Chem. Eng. Process. Process Intensif. 62, 106-113. https://doi.org/10.1016/j.cep.2012.08.005

Sinadinović-Fišer, S., Janković, M., Petrović, Z.S., 2001. Kinetics of in situ epoxidation of soybean oil in bulk catalyzed by ion exchange resin. JAOCS, J. Am. Oil Chem. Soc. 78, 725-731. https://doi.org/10.1007/s11746-001-0333-9

Suarez, P.A.Z., Pereira, M.S.C., Doll, K.M., Sharma, B.K., Erhan, S.Z., 2009. Epoxidation of methyl oleate using heterogeneous catalyst. Ind. Eng. Chem. Res. 48, 3268-3270. https://doi.org/10.1021/ie801635b

Törnvall, U., Orellana-Coca, C., Hatti-Kaul, R., Adlercreutz, D., 2007. Stability of immobilized Candida antarctica lipase B during chemo-enzymatic epoxidation of fatty acids. Enzyme Microb. Technol. 40, 447-451. https://doi.org/10.1016/j.enzmictec.2006.07.019

Turco, R., Pischetola, C., Tesser, R., Andini, S., Di Serio, M., 2016. New findings on soybean and methylester epoxidation with alumina as the catalyst. RSC Adv. 6, 31647-31652. https://doi.org/10.1039/c6ra01780k 
Vanoye, L., Wang, J., Pablos, M., De Bellefon, C., Favre-Réguillon, A., 2016. Epoxidation using molecular oxygen in flow: Facts and questions on the mechanism of the Mukaiyama epoxidation. Catal. Sci. Technol. 6, 4724-4732. https://doi.org/10.1039/c6cy00309e

Wentzel, B.B., Alsters, P.L., Feiters, M.C., Nolte, R.J.M., 2004. Mechanistic Studies on the Mukaiyama Epoxidation. J. Org. Chem. 69, 3453-3464. https://doi.org/10.1021/jo030345a

Wu, Z., Nie, Y., Chen, W., Wu, L., Chen, P., Lu, M., Yu, F., Ji, J., 2016. Mass transfer and reaction kinetics of soybean oil epoxidation in a formic acid-autocatalyzed reaction system. Can. J. Chem. Eng. 94, 1576-1582. https://doi.org/10.1002/cjce.22526

Xu, W., Ge, X.D., Cheng, D.L., Shao, R., Ding, J.F., Yan, X.H., Liu, T.T., 2017. Optimization of Epoxidized Methyl Acetoricinoleate Synthesis by Response Surface Methodology. Chem. Eng. Technol. 40, 571-580. https://doi.org/10.1002/ceat.201600044

Yan, M., Frank, E.M., Cochran, E.W., 2018. Effects of Vegetable Oil Composition on Epoxidation Kinetics and Physical Properties. JAOCS, J. Am. Oil Chem. Soc. 95, 209-216. https://doi.org/10.1002/aocs.12014

Zheng, J.L., Wärnå, J., Salmi, T., Burel, F., Taouk, B., Leveneur, S., 2016. Kinetic modeling strategy for an exothermic multiphase reactor system: Application to vegetable oils epoxidation using Prileschajew method. AIChE J. 62, 726-741. https://doi.org/10.1002/aic.15037 